\title{
Cyberbullying in Criminal Law Perspective
}

\author{
Ridwan Syaidi ${ }^{1}$, Suparno ${ }^{2}$ \\ \{syaidi.ridwan@gmail.com ${ }^{1}$, suparno@borobudur.ac.id² \\ Universitas Borobudur, Jakarta, Indonesia ${ }^{1,2}$
}

\begin{abstract}
This paper presents a criminal law perspective related to cyberbullying. The results of descriptive analysis using normative juridical methods equipped with a literature study of the legislation and related literature obtained the outcome of cyberbullying as a criminal act. The criminal law that covers cyberbullying is contained in Article $76 \mathrm{C}$ in conjunction with Article 80 (1) of the Child Protection Law.
\end{abstract}

Keywords: Children; Cyberbullying; Criminal

\section{Introduction}

Science and technology advancements brings society to adapt to the needs-based on these developments. One of the advancements in Science and Technology on the Internet is the interconnection between computer networks. But generally, the Internet is seen as a source of information. Internet content is information that can be imagined as an enormous and complete database or multimedia library. Not only that, the Internet is seen as a world in another form for almost all aspects of life in the real world are on the Internet such as business, entertainment, sports, politics, and so on.

Today using the term "virtual" as a substitute for the term "cyber." Because the definition according to the Indonesian Dictionary the word virtual seems to exist, but it doesn't exist and is only exists in imagination or fantasy. Along with human development from time to time, the human need for information and communication increasingly encourages humans to find and develop new, cutting-edge communication media, which allows humans to communicate and disseminate information quickly and precisely. With the process of discovering and developing communication and information media, then presenting a technology that can help accelerate Communication and information may flow freely without being hampered by place, boundaries, distance, or time, which can boost productivity and efficiency, which is then known as information and communication technology (ICT).

Access to information technology is used in various ways every day by the community is supported by the internet network. Until 2009 around 40 million Indonesians used the internet [1]. This figure is the highest in Southeast Asia. In Every person in Indonesia has the right to freedom, as stated in Article $28 \mathrm{E}$ paragraph 3: "everyone has the right to freedom of association, assembly, and expression," and Article $28 \mathrm{~F}$ : "everyone has the right to communicate and obtain information to develop his personal and social environment, and has the right to seek, obtain, possess, store, process, and convey information through all types of available channels." 
The right to freedom of association and assembly, as well as the right to express oneself verbally and in writing, are all protected by law. In this case, the provisions of Article 23 paragraph (2) of Law Number 39 of 1999 concerning Human Rights provide that "everyone is free to have, issue, and disseminate opinions according to his conscience, orally and or in writing, through print or electronic media, with observance of religious values, morality, order, public interest, and the integrity of the state".

Although the laws and regulations have provided freedom of expression, it is limited by laws whose purpose is to protect the dignity of every person. Someone is not forbidden to comment but must Rebe completed in a lawful and ethical manner. Everyone has the right to say what they think and thoughts, nevertheless, in reality, it is in terms of expressing opinions and thoughts which ultimately lead to acts that deviate from the rule of law as insults, harassment, slander, intimidation which can be charged with several articles contained in the Criminal Code as well as Information and Electronic Transactions Law. Even the treatment no longer occurs directly but can be done in cyberspace, through the internet world or also called cyberspace so that anything can be done in the internet world.

The advantages of this cyber world are appended to the trend of world technology development with all forms of human creativity. For those that are positive, it can provide many benefits and conveniences obtained from this technology, for example, being able to conduct banking transactions by e-banking at any time, and e-commerce also makes it easy for us to buy or sell an item without knowing the place. Looking for references or information about science is also not a difficult thing with the e-library and many more conveniences obtained with the development of the internet. Of course, it is undeniable that internet technology also has a negative impact that is not inferior to the existing benefits.

Cyberbullying is a phenomenon that occurs due to the negative influence of technological developments. Cyberbullying is a crime that is an extension of conventional bullying. Cyberbullying takes the form of verbal crimes in cyberspace, and the majority of victims are children [2]. Communication needs in cyberspace are used by children to establish social relationships with friends who are around them and new friends who have not been known before. The purpose of establishing relationships in cyberspace is also diverse from seeking information, establishing relationships with close friends, making new friends, and other reasons, to carry out social relationships in cyberspace, children use Facebook, Twitter, Instagram, and other social media sites can provide facilities to satisfy the desire and want to communicate. Adults and children who communicate via technology and the internet mean then cause the beginning of cyberbullying. Based on the above, this paper will present how the criminal perspective is related to cyberbullying.

\section{Methodology}

In this paper, the method used is normative juridical [3]. The data collection used in this paper uses a literature study, where the existing legislation and literature related to the research topic are used to build a constructive understandin [4]. The collected data is then analyzed using descriptive analysis to be presented comprehensively. 


\section{Results and Discussion}

Bullying is an act or series of negative actions that result in aggressive and manipulative behaviors carried out by one or more people against another person or several people over a certain period, containing acts of violence, and involving an imbalance of power. Perpetrators usually steal opportunities in carrying out their actions and intend to make other people feel uncomfortable/disturbed, while victims usually also realize that this action will happen again and again. Social media can be explained as a medium used to interact with people who are connected in a network. By using the connection, they can share, one to another about ideas or other information, whether text, images, or even videos.

Bullying in the form of insults carried out on social media, namely the instant messaging application Whatsapp, we refer to the Information and Electronic Transactions Law No. 11 of 2008. In principle, disdain for others is reflected in Article 27 paragraph (3) of the ITE Law, which states that "everyone willfully and without rights distributes, transmits, or makes available Electronic Information or Electronic Documents that contain charge of insult or defamation"[5].

Criminal threats for those who are condemned to a maximum of 6 years in prison and/or a maximum fine of Rp. 1 billion if they meet the requirements of Article 27 paragraph (3) and related to acts of humiliation on social media that were carried out together (more than 1 person) then those people were convicted of "committing" a criminal act (medepleger/accomplice). "To do" here in the sense of the word "to do together." There must be at least two people, the person who commits (pleger or perpetrator) and the person who participates in committing (medepleger or accomplice) a criminal event. The Criminal Code clearly regulates that insult is a The offense is a complaint. The Constitutional Court's judgement on the constitutionality of Article 27 paragraph (3) of the ITE Law, number 50/PUU-VI/2008, confirms that Article 27 paragraph (3) of the ITE Law is constitutional. is a complaint offense. It means that the case can be processed by law if there are complaints from people insulted on Whatsapp [6].

The elements of defamation, content, and context must all be understood. The only person who can judge the contamination or harm to a person's good name is the person who is being judged. To put it another way, the victim might subjectively determine which content or element of the Information or Electronic Document he believes has harmed his honor or reputation. Meanwhile, context plays a role in providing objective value to the content. Understanding the context includes an overview of the mood of the victim and perpetrator, the intent and purpose of the perpetrator in disseminating information, as the interests involved in disseminating content. Therefore expert opinion may be needed, such as linguists, psychologists, and communication experts to understand the context.

In this technological development, there are positive and negative sides. One example on the positive side is in the education field is the internet is a service that makes it easy to add insight, communicate, and also make it easier to find material that may be difficult to find in real terms. Through internet access, a person can add insight, communicate remotely, and also find much-needed information. The internet can help students to access various information and knowledge and share research among students, especially with those who live far away.

Internet technology also has a negative impact that is not inferior to the existing benefits, internet technology can be an effective means of unlawful acts. New crimes appeared along with the development of information technology and the internet. The crime called cybercrime or crime through the internet network threatens anyone with the lowest risk of being caught by individuals or groups, but with the result of greater losses for both the community and the 
state. Crime, in the cyber world, is a criminal and illegal act which in many cases can harm other parties. In this regard, the emergence Law Number 11 of 2008 Concerning Information and Electronic Transactions (UU EIT) was changed in 2016, and it became Law Number 19 of 2016 Amendments to Law Number 11 of 2008 Concerning Information and Electronic Transactions [7].

In national legal regulations, cyberbullying also has laws and regulations, namely Law No. 19 of 2016 as an Amendment to Law No. 11 of 2008 Concerning Information and Electronic Transactions, Article 27 paragraph (3) which states that "everyone intentionally and without rights distributing nor transmitting nor making Accessible electronic material or electronic documents containing insults or defamation might result in a maximum penalty of 6 (six) years in prison or a maximum fine Rp. 1. 0000.000.000.000 (one billion rupiahs)"[8].

Cyberbullying behavior interpreted in the Criminal Code is included in articles of humiliation, slander, threats, and decency acts. However, these articles have shortcomings to be applied to the realm of cyberspace. It is because the Criminal Code has made long before the development of cyberspace. The drawback is in the words "publicly known," and "publicly." According to the Constitutional Court Decision Number 50/PUU-VI/2008 states that the insults regulated in the Criminal Code do not reach the insults and defamation committed in the cyber world because there is an element of "in public." Including the terms "publicly known," "publicly," and "broadcast" is still insufficient. An extensive formulation is needed, namely "distribute" nor "transmit" nor "make accessible." The Criminal Code, when viewed from the regulation on humiliation, actually regulates humiliation in real life, while insults related to cyberbullying are carried out in cyberspace. The Criminal Code also does not provide a detailed explanation of what is meant by humiliation, so this can be a weakness [5].

Based on the formulation and regulation regarding cyberbullying in the Criminal Code and Information and Electronic Transactions Law No. 11 of 2008, as revised by Law No. 19 of 2016 as described above, it found that the Criminal Code has indeed been formed long before technological developments developed. In order to contain comprehensible rules against crime through the social world, Law No. 11 of 2008, about electronic information and transactions, has been renamed Law No. 19 of 2016, concerning electronic information and transactions. To deter cybercriminals from committing crimes (Cybercrime) by creating a sense of comfort and security for internet users [5].

\section{Conclusion}

In positive law, the cyberbullying regulations included in Chapter VII regarding prohibited acts in Articles 27-29 Amendments to Law No. 11 of 2008 Concerning Information and Electronic Transactions, by Law No. 19 of 2016. Meanwhile, the criminal provisions of the articles mentioned above regarding the crime of cyberbullying are regulated in Chapter XI of the criminal provisions. There are many stipulations govern in the ITE Law that cyberbullying vary, from defamation/insulting, slandering/spreading false news, spreading hatred and hostility. In determining cyberbullying sanctions, an act must look at the elements that meet each of the provisions in the ITE Law.

\section{References}

[1] N. Rulli, Teori dan Riset Media Siber [Cyber Media Theory and Research]. Jakarta: 
Kencana, 2014.

[2] S. Kalo, "Kebijakan Kriminal Penanggulangan Cyber Bullying Terhadap Anak Sebagai Korban [Cyber Bullying Criminal Policy Against Children as Victims.]," USU Law J., vol. 5, no. 2, p. 34, 2017.

[3] J. Ibrahim, "Teori dan Metode Penelitian Hukum Normatif [Normative Legal Research Theories and Methods]," Bayu Media, Malang, 2006.

[4] M. Abdul Kadir, "Law And Legal Research.," Bandung PT. Citra Aditya Bakti., 2015.

[5] Widodo, Aspek Hukum Pidana Kejahatan Mayantara. Yogyakarta: Aswaja Pressindo, 2013.

[6] Sartana and N. Afriyeni, "Perilaku Perundungan Maya (Cyberbullying) Pada Remaja Awal," Insight J. Psikol., vol. 1, no. 1, 2017.

[7] A. S. Sudarwanto, "Cyberbullying Kejahatan Dunia Maya yang 'Terlupakan' (Wacana Kritis Cyber Crimedi Negara Berkembang).,," J. Huk. Pro Justitia, vol. 27, no. 1, 2009.

[8] "Undang-Undang Nomor 19 Tahun 2016 Perubahan Atas Undang-Undang Nomor 11 Tahun 2008 Tentang Informasi dan Transaksi Elektronik.”. 